öz

Günümüzde konut üretiminde, kamu müdahalesinden çok piyasada üretimi belirleyen süreç ve koşulların etkili olduğu, giderek kamunun da piyasadaki aktörler gibi davranmaya başladığı görülmektedir. Türkiye'nin serbest piyasa ekonomisine geçmesiyle gelir dağılımı giderek bozulmaya başlamış, küresel ölçekte izlenebilen eğilimlere de uygun şekilde, lüks tüketime yönelen bir kitle ortaya çıkmıştır. Konut, artık bir yatırım aracı olduğu kadar, toplumsal statüyü de simgeleyen bir tüketim malı haline gelmiştir. Temel insan gereksinimlerinden olan konuta bu yaklaşım, planlama alanı açısından bazı sorun alanlarını gündeme getirmektedir. Barınma amacı ile tüm gelir grupları için yeterli ve erişilebilir konut alanları planlaması yaklaşımının yetersizlik gösterdiği, piyasa süreçleri içinde kentin çeperlerine yerleşerek kentin yayılmasında belirleyici olan yeni kapalı sitelerin oluşturulduğu görülmektedir. Bu yaklaşım, kent planlamanın doğası ile çelişmektedir. Makalenin amac1, mevcut konutlaşma eğilimleri içinden kapalı sitelerin tüketim toplumu açısından tartışılması ve bu tür konutlaşmanın kent planlama disiplini açısından değerlendirilmesidir. Tartışma, İstanbul kentinin konut üretim dinamikleri ile örneklenecektir.

Abstract

Private sector investments are the leading factor of housing production today while public agents become a part of the housing market, instead of controlling it. A new consumerist segment in the society has emerged in Turkey after the transition to free market economy, in line with the global tendencies. Luxury housing became an instrument for investment as well as a sign of social status of the inhabitants. Housing production, which is a human right, without public control leads to problems in the field of urban planning. On the one hand, there is a shortage of affordable housing production, on the other development of gated communities surround periphery of the cities. Not only gated communities but also housing development projects in inner cities became the commodities of free mar ket, which constitutes a contradiction with the nature of the planning. The aim of this article is to discuss the gated communities, which epitomize commodified housing production in the frame of consumer society, referring to Istanbul.

Anahtar kelimeler:

Tüketim toplumu, kapalı siteler, konutlaşma, yaşam tarzı, sosyal ayrışma Keywords:

Consumerist society, gated communities, housing, life style, social segregation

\title{
Tüketime Bağlı Bir Kimlik Öğesi Olarak Konut ve Planlama Açısından Bir Değerlendirme
}

\author{
Ebru Firidin ÖZG $\ddot{U} R$ \\ Mimar Sinan Güzel Sanatlar Üniversitesi, \\ Mimarlık Fakültesi, Şehir ve Bölge Planlama Bölümü
} * Bu makale, 14-16 Aralık 2007 tarihlerinde Bahçeşehir Üniversitesi’nde İT̈̈ ortaklı̆̆ı ile düzenlenen IAPS Kent Konut Kültür
Sempozyumu'nda sunulan "Tüketime Bağlı Bir Kimlik Öğesi Olarak Konut" isimli bildiriden geliştirilerek yazılmıştır.

Konut, alt gelir grupları için barınmanın karşılanacağı yer olarak temel ihtiyaçlardan birisi, üst gelir grupları içinse daha prestijli ve konforlu olanı inşa edildiğinde yenisi satın alınacak bir tüketim nesnesi ve aynı zamanda kârlı bir yatırım aracı haline gelmiştir. Konut, kişilerin ve ailelerin yaşam tarzının ve toplumsal statüsünün en önemli göstergelerinden birisini oluşturmaktadır. Toplumsal düzeyde gelir dağılımındaki dengesizlik arttıkça, konut piyasasında tüketime ve yatırıma yönelik olarak konut üretimi de artmakta, böylece konut alanları arasında satın alma gücüne bağlı farklılıklar da belirginleşmektedir. Bu durum, bir yandan tüketim toplumu dinamikleri ile belirlenirken, diğer yandan toplumsal ayrışmanın mekânsal açıdan görünürlüğünü de artırmaktadır.

Türkiye de yukarıda genel hatları verilen durumun yaşandığ Ekonomide liberalleşmenin, yalnızca ülkenin ekonomik yapısını değil, toplumsal yapısını da derinden sarsan sonuçları olmuştur. İstanbul, bugün, hedeflendiği gibi hizmetler sektörüne geçişini tamamlamamış olmakla birlikte, serbest piyasa ekonomisine geçiş sürecinde, yeni istihdam alanları açılmış, daha önce etkin olmayan (reklamcllk, medya, sigorta gibi) sektörler güçlenmiş ve yeni orta sinıf olarak da adlandırılan bir kesimin oluştuğu görülmüştür (Bali, 2002; Işık ve Pınarcıoğlu, 2003). Bu süreçte, İstanbul'da istihdam yeniden yapılanırken, yeni istihdam yapısı içinde gelir dağılımının değişmesiyle daha önce kullanılmayan mal ve hizmetlere talep gösteren bir tüketici kitlesi ortaya çıkmıştır. Bu yeni kesim, yaşam tarzı açısından yeni arayışlara girmiş, bu durum da konuttan eğlenceye, kentin toplumsal ve mekânsal yapısı üzerinde etkili olmuştur.

Günümüz konut alanlarının oluşumu birbirinden bağımsız olmayan iki açıdan irdelenebilir: ilki, konut piyasasını oluşturan temel dinamikler olarak üretim süreci; ikincisi ise tüketim boyutunu yani talep sürecini biçimlendiren dinamikler. Üretim sürecine ilişkin yapılanma, planlama yönlendirmesinden çok serbest piyasa koşullarına bağlı olduğundan ve toplumsal eşitlik temelli kamu müdahalesi 
zayıf kaldığından konut, bir barınma hakkı olarak ele alınmaktan uzaklaşmıştır.

Kamu, bir yandan belli kurumları ile konut üretimini denetim altında tutmak ve yönlendirmek çabasında görünürken, diğer yandan bu kurumların piyasadaki bir aktör gibi hareket ettiği görülmektedir. Konut edindirme amaçlı üretilen dar gelirli konutları yaşam kalitesi sunmaktan uzaktır, ancak diğer bir yandan da kamu kurumlarının yüksek gelir grubuna yönelik konut sunumunda bulunduğu görülmektedir. Diğer yanda ise; tüketimin yani talep kısmının bilinmesi, toplumsal ve kültürel yeniden yapılanmanın anlaşılması açısından önem taşımaktadır. Tüketim toplumunun dinamiklerine bağlı olarak serbest piyasa koşulları içinde, konut piyasası da yeni yönelimlere girmiş ve bir barınma hakkı olarak konut üretimi gözden çıkarılırken, kârlılık koşullarına göre pazarlanan konut alanları oluşturulmaya başlanmıştır. Bu alanlar, sunumları birbirine çok benzer olmakla birlikte farklı bir yaşam tarzı etiketi ile pazarlanmaktadır. İstanbul'un mevcut konut alanlarında yaşam kalitesini sağlayacak kentsel donatı alanlarının oldukça niteliksiz olması ve deprem tehdidi, yeni inşa edilen ya da yenilenen alanları üst gelir grupları için tüketim açısından çekici hale getirmektedir. Bu durum, konut piyasasında hanelerin gelir düzeylerine bağlı olarak bir eşitsizliğe yol açmaktadır.

Konutun bu şekilde bir tüketim metası haline gelmesi, tüketim toplumu paradigması ile açıklanmaktadır. Tüketim toplumunun içinde bulunduğu tüketim kültüründe kimlikler, kişiye has özellikler üzerinden değil, toplumsal statüyü belirleyen tüketim kapasitesi ile belirlenmektedir (Le Goix, 2003). Bu açıdan kişilerin yer ile ilişkisi de tüketimle bağlantılı hale gelmektedir. Tüketimin belirlediği bu ayrışma süreci içinde, kentlilerin yer ile ilişkisinin belirsizleşmesi dolayısıyla kamusal alanların da aşınması söz konusu olmaktadır. Kamusal alanlar, giderek özelleşen alanlar haline gelmektedirler. Giriş kontrollü alışveriş merkezleri, izinsiz girilemeyen konut alanları kamusal olması beklenen alanları ve donatıları sahte-kamusal alanlar haline getirmektedir. Böylece, kentsel mekânın kamusal anlamı da tüketilmekte, farklı yaşam tarzlarına hitap eden sahte-kamusal alanlar üretilmektedir. Bununla birlikte planlama açısından yalnızca kamusallığın ve kentselliğin ortadan kalkması değil, çok daha fazla sorunu da beraberinde getirmektedir. Bir yandan kentsel büyümenin denetim altına alınması açısından sorunlar oluşurken, diğer yandan yerel ölçekte konut alanlarının planlanmasının temel ilkeleri ortadan kalkmakta, dolayısıyla birbirleriyle bütünleşerek kenti kuran mahalle olgusunun yerini, parçalanmış konut siteleri almaktadır (Firidin Özgür, 2011).

Yukarıda açıklanan çerçevede Türkiye'de ve özellikle İstanbul'da ortaya çıkan tüketim toplumu çerçevesinde konut tüketim biçimlerinin irdelenmesi; bunun konut piyasasındaki yansımalarının ve sonuçların izlenmesi önem taşımaktadır. Tüketim toplumunda konutun anlamı değişmektedir. Konut piyasası açısından bu sürecin en önemli sonuçları, konut sorununun bir barınma sorunu olmaktan çıkarak, kentsel rantın paylaşım sürecine dönüşmesidir. Bu paylaşım sürecinde konut, üst sınıflara pazarlanırken yaşam tarzını gösteren bir statü simgesi haline getirilmektedir. Tüketim kültürü, konutun pazarlanmasının altyapısını oluşturmaktadır. Bu çerçevede, makalede önce tüketim toplumu ile konut tüketimi 
arasındaki ilişki ele alınacaktır. Bundan sonra kent planlama açısından, bir tüketim malı haline gelen kapalı sitelerin planlama açısından değerlendirilmesi yapılacaktır. Bu iki kısmın ardından, İstanbul'da kapalı siteler ele alınarak, konut üretiminin temel aktörlerinden olan TOKİ'nin kapalı site üretimindeki rolüne değinilecek ve 2009 yılında yapılan Çevre Düzeni Planı (ÇDP) bu açıdan değerlendirilecektir. En son kısımda ise; sonuç ve değerlendirmelere yer verilecektir.

\section{Tüketim Toplumu ve Kapalı Siteler}

Günümüz kentsel toplum yapısındaki temel eğilimler, tüketim kültürünün belirleyici olduğu bir işleyiș göstermektedir. Tüketim kültürünün yönlendirdiği bu toplum yapısına, tüketim toplumu denmektedir (Baudrillard, 2004). Bu yapılanmada, her şey bir tüketim nesnesine dönüştürülerek, yani metalaştırılarak piyasa içine çekilmekte ve tüketilebilir hale getirilmektedir. Böylece tüm toplumsal ve insani değerler de bu metalaşma sürecinden pay almaktadırlar.

David Harvey'in $(2001,409)$ çarpıcı ifadesiyle: "Her şeyin arsızca metalaştırılması ve ticarileştirilmesi, zamanımıza vurulan damgalardan biridir." Piyasa mekanizmaları içinde, sanayi ürünleri ve hizmetler, toplumsal yarar değil, tüketilebilirlik, yani ekonomik kârlılık ve pazar payı açısından değer kazanmakta, bu amaçla işlenmektedirler. Piyasa açısından ürünlerin, metaların pazarlanabilir olması için bir kimlik ve statü öğesi olarak sunulması gerekmektedir. Bu da ürünlere yüklenilen anlamlarla gerçekleştirilmektedir. Örneğin, deterjanlar temizlik ve saflığa erişmek, yeni bir ev satın almak ise yeni ve sorunsuz bir hayata adım atmak olarak nitelendirilebilmektedir (Barthes, 1998; Öncü, 1999). Bu açıdan bakıldığında barınma açısından temel ihtiyaç olan konutun da tıpkı bir deterjan gibi pazarlanabildiği görülmektedir.

Seri üretimin zaruri kıldığ 1 toplu tüketim artık prestij, seçkinlik, yaşam tarzı ve hatta kimlik açısından belirleyici olan bir kodlar dünyası oluşturmaktadır. Tüketim kültürünün içerdiği bu kodlar dünyasında seçilen imajlar, tüketim kapasitesi (gelir) ile birlikte sınıfsal konuma da işaret etmektedir. Bu kodlar dünyasına dahil olma, kimlik üzerinde, farklılaşma ve özdeşleşme yoluyla belirleyici olmaktadır. Baudrillard (2004), tüketim toplumuna ilişkin çalışmasında, mevcut sistemin işlemesi için tüketimin gerekliliğini açılarken, bunu toplumda farklılıklar üreterek gerçekleştirdiğini vurgular: Büyümenin çelişkilerinden biri aynı anda mal ve ihtiyaç üretmesi, ama bunu aynı ritimde üretmemesidir; mal üretiminin ritmi endüstriyel ve ekonomik üretkenliğin bir işlevi, ihtiyaç üretiminin ritmi ise toplumsal farklılaşma mantığının bir işlevidir (Baudrillard, 2004, 71).

Ekonomik işlev ile toplumsal farklılaşma talebi yaratma arasındaki bağlantı ve ilişki, pazarlama faaliyeti ile kurulmaktadır. Toplumsal ve kişisel gereksinimler, üretime göre biçimlendirilmekte ve yönlendirilmektedir. Bu da yeni ürünlerin pazarlanması için yeni ihtiyaçların icat edilmesini gerektirmektedir.

Baudrillard (2004, 90), tüketimin mantığında yer alan ihtiyaç kavramının aslında herhangi bir "nesneye duyulan ihtiyaç değil, farklılık ihtiyac1 (toplumsal anlam arzusu) olduğunu" belirtir (vurgu yazara ait). Günümüz tüketim toplumunu yaratan olgular bütünü; tüketim alışkanlıklarının, sanal olarak üretilen ihtiyaçlar etrafında örgütlenmesinden ve güdümlenmesinden 
yani tüketim kültüründen kaynaklanmaktadır. Tüketim artık basitçe ihtiyaçların karşılanması değil, kimliğin yeniden üretimini ve sınıfsal göstergeleri oluşturan ve belirleyen bir tercihler ve olanaklar sistemidir.

Tüketim toplumunu hayata geçiren dinamikler, kitleleri sınıfsal olarak aynı anda aynı şeyi tüketmeye zorlayarak bir yandan tektipleştirirken, diğer yandan tüketilen nesnenin göstergelerine göre farklılaştırmaktadır (Baudrillard, 2004;

Bourdieu, 1995). Sınıfsal olarak erişilebilir olan nesnelerin piyasadaki yerleri, içerdikleri toplumsal anlam ve göstergeleri zamana göre değişkenlik göstermektedir. Bourdieu (1995) bu durumu, toplumsal uzamın simgesel uzam ile ilişkisi içinde kavramlaştırır. Her bir toplumsal grubun, kendi sınıfsal yapısına göre gelişen bazı pratikleri olduğunu belirtir ve bunu "toplumsal konumlar kümesi" olarak adlandırır. Buna göre yaşam tarzını belirleyen göstergeler, zamana bağlı olarak değişebilmektedir.

Kısacası, zamanın belli bir anında ve olabilecek mal ve pratik arzının belli bir durumunda, herhangi bir gruba (soylular, samuraylar ya da işçiler, memurlar) ait olabilecek özellikleri o gruba ilişkin ve gerekli özelliklere dönüştürmemeye dikkat etmek gerekir. Böylece, her toplumun, her anında, bir toplumsal konumlar kümesi ile karşı karşıya kalırız; bu küme, kendileri de bağıntısal olarak tanımlanan, belli bir etkinlik (golf ya da piyano pratikleri) ya da mal (yazllk ev ya da ünlü ressamların tabloları)

kümesine benzeşiklik (homologie) bağıntısıyla bağlanmıştır

(Bourdieu, 1995, 19, vurgu yazara ait).

Konut bir tüketim nesnesi olarak ele alındı ̆̆ında statü, anlam ve göstergelerden

$32 \mid$ sayı 14, 2012 bağımsız değildir; konut piyasada talebe göre üretilerek pazarlanan bir meta olarak farklılaşmanın ve ayrışmanın aynı zamanda da kendileri gibi olanlarla özdeşleşmenin araçlarından birisi haline gelmektedir. Bu da genel olarak, konut alanlarının bir yaşam tarzı sunduğu argümanı ile pazarlanmasına yol açmaktadır. Bourdieu'nun (1995) yaklaşımı ile yorumlandığında, statü göstergesi olarak konutun yüklendiği anlamlar da sınıfsal olarak zamana göre değişebilir ve bugün üst ve orta sınıflar için bir statü göstergesi olan bir konut türünün yerini yarın başka bir tür konut alabilir.

Konut alanlarının yeni pazarlanma biçimlerinin oluşmasında, kentsel rantın azamileştirilmesi önem taşımaktadır. Konutun yalnızca barınma ihtiyacını karşılamanın ötesinde kişiye güvenlik, özelleştirilmiş hizmetler, bakımlı bir çevre, teknolojik kolaylıklar ve bunlarla birlikte tüketim kültürü içinde yükselen değerlere sahip olma yoluyla ayrıştırıcı bir kimlik sağlaması, piyasa değerini yükselten etkenler olarak devreye girmektedir. Kapalı siteler, rezidanslar hatta kentsel dönüşüm alanları, tüketime sunulan farklılığa, seçkinliğe vurgu yapılarak pazarlanmaktadırlar. Herkesten farklı olanaklara sahip olma ayrıcalığı, konuta ek olarak satılmaktadır (Resim 1,2).

Burada konutun kullanım değerinin yerini, değişim değerinin olabilecek en yüksek düzeye çıkartılması almıştır. Kullanım değerinden soyutlanması, konutun barınma gereksinimi açısından tanınan temel bir insan hakkı olmaktan çıkarak, hedeflenen gelir gruplarının aradıkları yeni kimlik alanlarının yaratılmasını destekleyen piyasa süreçlerine terk edilmesi anlamına gelmektedir. 

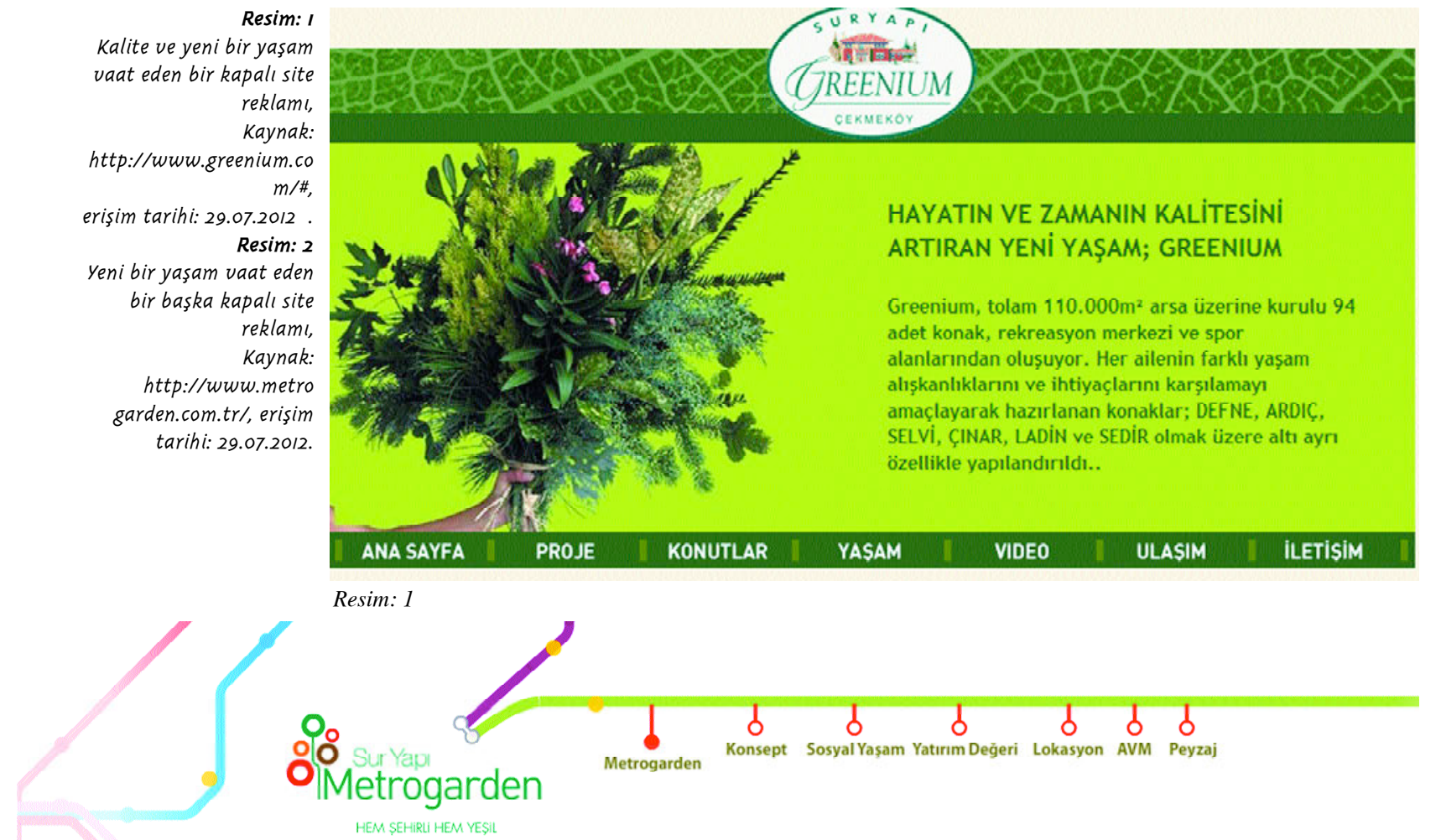

Metrogarden Sizi yeni yaşamını HEM YEŞ

Resim: 2

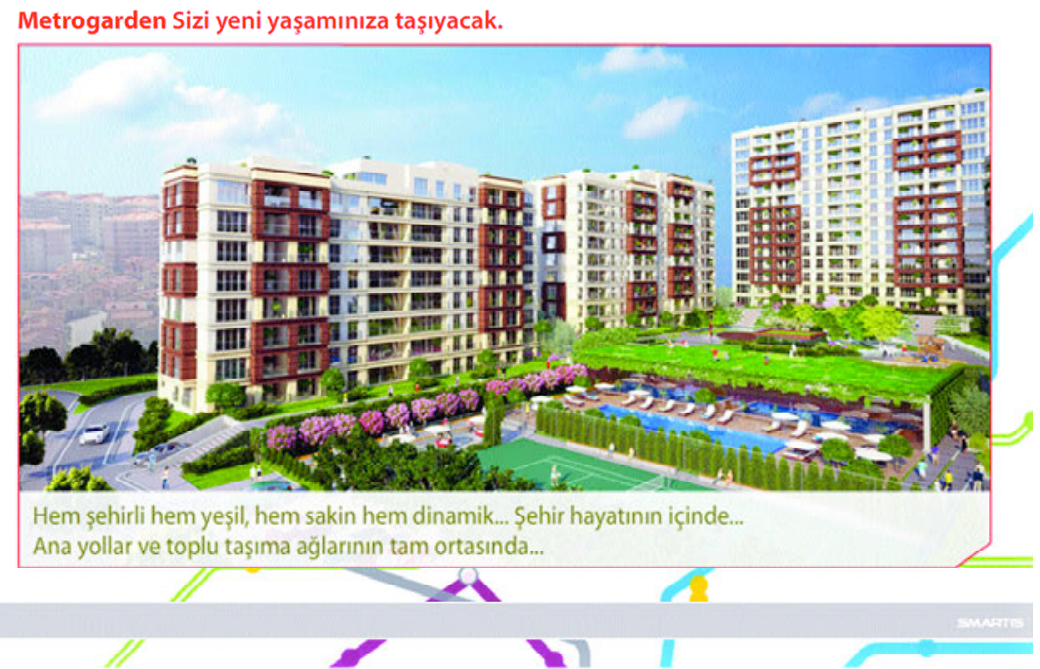

Tüketim kültürü ile farklı olma, lüks yaşam, ayrıcalıklı yaşam gibi yükselen değerlerin Türkiye ve özellikle İstanbul'da yerleşmesinin, 1980'lerde ortaya çıkan yeni zengin olarak da adlandırılan yeni orta sınıfların oluşması ile gündeme geldiği belirtilmektedir. Batılı yaşam biçimlerine sahip olma arzusu, hakim medya tarafından da desteklenmiştir (Öncü, 1999; Keyder, 2000; Bali, 2002; Işılk ve Pinarcıŏglu, 2003). Batılı tarzda yaşama eğilimi, konut tercihinden gündelik tüketime kadar her alanı etkisi altına almış ve tüketme kapasitesi olanlar, seçkin bir azınlık içinde yer alma adına yaşam alanlarını farklılaştırmaya başlamışlardır. 
Burada toplumun bir çözülme içine girmesinin yarattığı tehlikeler dikkat çekmektedir. Toplumsal ayrışma, 1990'larla birlikte yeni yapılanan konut alanlarıyla da belirginleşmiş, yeni 'ayrıcalıklı' konut siteleri bir kimlik göstergesi haline gelmiştir.

Dışlayıcı davranışlar içine giren tüketici kitlesinin farklılaşma ihtiyacının piyasa tarafından körüklenmesi, bu konutların pazarlanmasında kullanılan argümanlarda da izlenebilmektedir. Birbirine çok benzer olmakla birlikte, kapalı sitelerin bir yaşam tarzı, farklılık ve toplumsal statü sattığı görülmektedir. Kapalı siteler kentin (tekinsiz) kalabalığından uzak, ama kentin nimetlerine yakın olmalarını (karayoluna bağlı göreli ulaşım kolaylı̆̆ı), güvenlikli olmalarını (özel güvenlik görevlileri, kapalı devre kamera sistemi ve duvarlarla çevrelenmiş olmaları), içerdikleri kimi ortak kullanım hizmetlerini (spor alanları, yeşil alanlar, sosyal tesisler) ve son olarak eğer varsa konumsal özelliklerini (orman alanlarına yakın olma ya da örneğin Boğaziçi ve deniz, manzarası) inşaat kalitesi (son teknoloji, depreme dayanıkl, modern, çağdaş ya da geleneksel kodlara sahip) ile birleştirmekte ve bunları bir prestij öğesine dönüştürerek pazarlamaktadırlar (Firidin Özgür, 2006). Bu özellikleri ile pazarlanan konut alanları, seçkin yaşam tarzı ve kazançlı yatırım talebini karşılamaktadırlar. Le Goix (2003, 2), kapalı sitelerin "emlak sanayisi tarafından üretilen tüketim malları olarak görülmesi gerektiği" yorumunu yaparken, aynı zamanda bu durumun planlamanın içsel değerleri ile çeliştiğini ifade etmektedir. Ortaya çıkan lüks talebi böylece konutlaşma açısından da yeni bir yaklaşımı doğurmuştur.

Bu yaklaşım içinde kapalı sitelerin, toplumsal tüketim kültürü içinde vaat ettiği ilk ve en önemli özellik, Baudrillard'in da tüketim kültürü çerçevesinde belirttiği gibi diğerlerinden farklı olanaklar içinde "ayrıcalıklı" bir yaşam tarzıdır. Burada yeni zenginlerin ya da yeni orta sınıfın toplumun geri kalanından ayrışma talebi içinde olduğu tespiti yapılmaktadır (Bali, 2002; Işık ve Pınarcıoğlu, 2003). Kontrollü giriş kapıları, güvenlik görevlileri ve kameraları ile 24 saat koruma sağlayan bu tür konutlaşma, bir yandan kentin kalabalığından kaçmayı ve kendi gibi olanlarla birlikte yaşamayı, diğer yandan kentin diğer yerlerinde bulunmayan bir ayrıcalık dünyasına girişi sağlamaktadır. Işık ve Pınarcıŏglu (2003), kentleşme süreci içinde konutlaşmadaki farklı grupların davranışlarını, hem toplumsal statü kazanma ve kentsel ranttan pay alma hem de kentte tutunma savaşımı olarak ele almaktadırlar: 1980’li yılların Türkiye'sinde kentleşme süreçlerine damgasını vuran, farklılaşma ya da çeşitlenme ile ortaya çıkan ayrışma eğilimleridir. Bir uçta, kentin çeperinde eskisinden çok farklı yöntemlerle ve ilişkilerle varlığını sürdürmeye çalışan ve bu uğurda daha önceden yapmayı tasavvur bile edemeyeceği çok şeyi yapmaya hazır kent yoksulları; arada bir yerde kooperatifler yoluyla kentteki paylaşım kavgasına katılan ve kent çeperindeki geniş arazilere göz diken orta sınıflar; diğer uçta, kentin en prestijli alanlarında 'kapattı̆̆ı' arazilerde özel güvenlik sistemleri ile korunan yüksek duvarların ardında yaşayan ve artık değil terk ettiği kente, topluma bile dönüp bakmayan üst sınıflar (Işılk ve Pınarcıoğlu, 2003, 128).

$\mathrm{Bu}$ tespite göre, konut edinme alt ve orta sinıflar için toplumda tutunma ve konumlarını sabitleme açısından paylaşım savaşı ile elde edilen bir güvence oluştururken, üst sınıflar için bir prestij aracı, aynı zamanda da kendilerini 
yalıtmanın bir yolu olmaktadır. Benzer şekilde Atkinson (2006) da toplumdaki ayrışmanın mekândaki parçalanmayı güçlendirdiğini ifade etmektedir:

Eşitsiz bir toplumda, grupların belli bir yerde kümelenmeleri, başta gelire bağlı olarak ama aynı zamanda toplumsal kimlik, yaşamda hangi evrede oldukları ve aile tipine göre sosyo-mekânsal ayrışma ile sonuçlanmaktadır (Atkinson, 2006, 820).

Yeni bir kimlik öğesi olarak konutun ortaya çıkışında, tüketim toplumu olgusunun yanı sıra bir takım diğer etkenlerden de bahsedilebilir. Bunlar, kentlerin yapılanmış alanlarının sunduğu yaşam koşulları ile bağlantılı ve tüketici kitlesini, yeni konut alanlarının sunduğu bir takım avantajlardan yararlanmaya iten etkenler olarak ele alınabilirler.

Kentsel donatıların yetersizliği dolayısıyla mevcut kentsel alanların yaşanabilirliğinin azalması, önemli etkenlerden birisidir. Başta, özel araç sahipliğinin de hem bir statü simgesine dönüşmesi hem de toplu ulaşım olanaklarının gelişmemişliğ $i$ dolayısıyla kişiler için bir seçenek haline gelmesi dolayısıyla artması sonucu otopark ve donatı yetersizliği, otomobile bağlı yaşayan kesimler için site yaşamının tercih edilmesini güçlendirmektedir. Çocuk sahibi olma ve aile odaklı bir yaşam da kentsel donatılar açısından daha zengin olan sitelerin tercih edilmesinde etken olarak görülmektedir. Mahalle dokusunun hem toplumsal olarak ayrışması, hem de mekânsal olarak parçalanması, çocuk yetiştirmede kapalı sitelerin sunduğu "güvenlikli" ortamı bir seçenek haline getirmektedir. Kapalı sitelerde yaşayan kişiler, site ortamının çocuklar için uygun bir ortam olduğunu belirtmektedirler (Firidin Özgür, 2006). Diğer yandan İstanbul özelinde, deprem tehdidi altındaki yıpranmış yapı stoku da yeni konutların tercih edilmesi ile sonuçlanmaktadır. Yeni üretilen konut alanlarının çoğunun pazarlanmasında depreme dayanıklılık, fazladan bir özellik olarak sunulmaktadır. Kentlerin kalabalıklaşarak güvenliğin azaldığı yerler haline gelmesi de bir diğer argüman olarak sunulmaktadir.

Dolayısıyla sitelerin sundukları avantajlar, kentin sunumundaki yetersizlik ve toplumsal ayrışma ile birleştiğinde, yaşam tarzı ve statüyü simgeleyen çekim odakları haline gelmelerini sağlamaktadır (Firidin

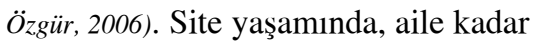
yatırımların güvenliğinin sağlanması da önem kazanmakta, siteler sayesinde çocuklarla birlikte otomobiller ve konuta yapılan yatırım da güvence altına alınmaktadir. Mike Davis (1992), Los Angeles'ın tek aile evlerinden oluşan alt kentlerinin (banliyölerinin) üç temel yaşam gerçeği olduğunu ileri sürmektedir:

İlki, Los Angeles'ta ev sahipleri, çocuklarını severler, ama mülklerinin değerini daha çok severler; ikincisi, Los Angeles'ta topluluk, ırk, sınıf ve özellikle emlak değerlerinin homojen olması demektir ve üçüncüsü, günümüz güney Kaliforniyasında en güçlü 'toplumsal hareket' zengin ev sahiplerininkidir: ulusal topluluk ünvanları ya da bölge isimleri ile organize edilen, konut değerlerinin ve mahalle dışlayıcılığının korunmasına yönelik hareket (Davis, 1992: 153).

Bu durum İstanbul'daki site sakinleri için de geçerlidir. Kapalı siteler yalnızca ayrıcalıklı bir yaşam değil, sürekli bakımı yapıldığ 1 ve koruma altında olduğu için, mülk sahiplerine emlak değerini kaybetmeme güvencesini de sunmaktadirlar. $\mathrm{Bu}$ açıdan kapalı siteler, konut sahipleri için karlı bir yatırım olarak görülmektedirler. 
Kapalı siteler, bir yandan toplumsal statü arayışı içinde, tüketim toplumu dinamiklerinin ve toplumsal ayrışmanın bir ürünü olurken, burada yaşayanlar kentin sunduğu dezavantajları tercihin asıl gerekçesi olarak öne sürmektedirler. Sonuç olarak yeni tüketim eğilimleri çerçevesinde incelendiği zaman, kapalı yerleşmelerin sosyal ve mekânsal ayrışmayı güçlendirdiği görülmektedir. Kapalı yerleşmeler, kişilerin kendilerini diğerlerinden, ötekilerden ayırmalarına yararken, kent mekânını da parçalamaktadır (Blakely ve Snyder, 1999; Firidin Özgür, 2006; Erkip, 2010).

\section{Kent planlama açısından kapalı siteler}

Üst sınıfların sosyal ve mekânsal olarak kendilerini ayrıştırma talepleri, günümüzde kapalı yerleşmelerin üretilmesi ile karşılığını bulmaktadır. Farklı gelir gruplarının yaşadıkları mahalleler her zaman birbirinden farklılık göstermiş olmakla birlikte (Erkip, 2010), bu toplumsal ayrışmanın sınırları belirsizdir. Ayrıca bu mahalleler, mekânsal olarak yalıtılmış değillerdir. Oysa yukarıda da değinildiği gibi kapalı siteler, kendini ayrıştırmanın bir sonucu olarak ortaya çıkmakta, toplumsal ayrışma ve mekânsal parçalanmayı güçlendirmektedir.

Kapalı siteler olarak biçimlenen yeni konut tüketim biçimi, kent planlama açısından da belli bir takım sonuçları beraberinde getirmektedir. Bunlardan belki de en önemlisi, kentlerdeki sosyal ayrışmanın mekânsal olarak görülür ve hissedilir hale gelmesidir. Bununla birlikte, genellikle özel sektöre bırakılmış olan konut üretiminde, piyasa koşullarının geçerli olduğu ve her gelir grubundan insan için yeterli konut üretiminin yapılmadı̆̆ 1 görülmektedir. Özellikle İstanbul'da arsa değerlerinin giderek yükselmesi, toplumsal adalete ilişkin

36 sayı 14, 2012 değil, kentsel arsa değeri artışından en fazla faydalanmaya yönelik politikaların geçerli hale gelmesine yol açmaktadır.

Yukarıda değinildiği gibi, mevcut kentsel alanların yaşam niteliğinin düşük olması da kapalı site tarzı kapalı konut alanlarını çekici hale getiren etkenlerden birisidir. Kent planlama açısından bakıldığında, burada bazı sorun alanları tespit edilebilir. İlki, konutlaşmada bu türden ayırıcı yapılanmalar, toplumsal bütünleşmeyi tehdit etmektedir. Toplumsal ayrışma mekânsal olarak da güçlenmektedir. Toplumsal ayrışmanın güçlenmesi ve bütünleşmenin giderek zorlaşması, Işık ve Pınarcıŏ lu'nun (2003) tanımladığı gibi, "kentten çekilen" kesimlerin, yani kentin geleneksel olarak kamusal mekânları olarak tanımlanan alanlarını artık kullanmayan kesimlerin, "terk ettikleri kente dönüp bakmamaları" sonucunu doğurmaktadır. Bu durum, farklı grupların birbirlerini ötekileştirmesine, kente aidiyetin ortadan kalkmasına, hemşerilik, yani aynı kenti paylaşan kişiler olma hissinin ve giderek, Blakely ve Snyder'1n (1999) tabiriyle, "vatandaşlık bilincinin" ortadan kalkmasına neden olmaktadır.

İkincisi, yerel yönetimlerin kapalı siteler ile ilgili bir denetim sistemi oluşturmadı $\breve{g} 1$, aksine emlak gelirlerinin yükselmesi ve bakım maliyetinden kurtuldukları için kapalı sitelerin oluşumunu destekledikleri ya da en azından bir sorun olarak algılamadıkları görülmektedir. Ancak siteler, konut alanları planlamasında temel birim olan mahalle örgütlenmesinin karşısındaki en büyük tehditlerden birisini oluşturmaktadır. Günümüzde insan ilişkilerinin zayıflaması ve örneğin, okulun artık mahalle okulu olmaktan çıkması, yani kentsel hizmetler etrafında düzenlemenin geçersiz kalması, mahalle 
kavramını sorgulanır hale getirmiştir (Firidin Özgür, 2011). Dolayısıyla, kapalı sitelerin konut alanlarındaki ilişki ve örgütlenmeye etkileri de daha derinlemesine irdelenmeli ve tartışılmalıdır.

Gelişmiş ülkelerde, kapalı sitelere karşı uygulamada yönlendirici olabilecek farklı yaklaşımların geliştirildiği görülmektedir. Kanada'da yapılan bir araştırma projesinin sonuçları, yerel yönetimlerin kapalı sitelere yönelik farklı stratejiler izleyerek inşa sürecini engelledikleri ve denetim altına almaya çalıştıklarını göstermektedir (Grant, 2003). Bu araştırmaya göre Kanada'daki toplam 241 kapalı site belgelenmiş ve belediyelerin aldıkları önlemler, 5 farklı kategoride ele alınmıştır. Bu kategoriler, planlama politikalarından tasarım stratejileri ve müzakereci yaklaşımlara (ikna süreci) kadar farklı ölçek ve kapsamlarda uygulanmıştır. Çalışmada, bu planlama araçları aşağıdaki gibi kategorize edilmiştir (Grant, 2003):

1. Planlama politikaları ve arazi kullanımı / bölgelemeye dair yönetmelikler

2. Mühendislik ve acil durumlarda erişim politikaları

3. İmar sözleşmeleri ve ruhsat süreci düzenlemeleri

4. Belediye meclisi kararları ve yönetmelikler

5. Yerel yönetim çalışanlarının girişimcileri ikna etmesi

Bu örnekte, planlama süreci içinde kapalı sitelerin kentle bütünleşmesine yönelik olarak ya da baştan bu türden konut alanlarının inşasını engelleyecek yaptırım araçlarının tanımlandığı ve uygulandığı görülmektedir. Dökümü yapılan 241 site içinde yalnızca 10 tanesinde güvenlik görevlisi ve 11 tanesinde kamera ile izlemenin bulunduğu belirtilmiştir (Grant, 2003). Bu rakamlar da planlama politikalarında belli oranda başarı olduğunu göstermektedir.

Farklı bir planlama sisteminin geçerli olduğu İngiltere'de ise kapalı sitelere karşı belli bir strateji izlenmediği, ancak belediyelerin yaklaşımları ve yörede yaşayan halkın tepkilerine göre yerel yönetimlerin, merkezi yönetimin planlama politikalarına da uygun şekilde, kapatılmaya karşı farklı tavırlar geliştirdikleri belirtilmektedir (Gooblar, 2002). Bu çalışmada, Londra' daki iki farklı ilçe belediyesinin kapalı site yapılmasına karşı farklı tavırlar sergiledikleri gösterilmiştir. Londra'da yüksek gelir grubunun yaşadığı Kensington ve Chelsea Belediyesi Earl's Terrace konut projesinde kap1 yapılmasına, plan hedeflerine aykırı olduğu dolayısıyla planlama birimince izin verilmediği aktarılmaktadır. Bölgede yaşayan halkın da projeye itirazları bulunmaktadır. İtirazlar, proje ile mahallenin kentsel ve toplumsal dokusunun bozulmasına yol açacağı noktasında birleşmektedir. Ayrıca bu karara dayanak olarak merkezi yönetimin "toplumsal bütünleşme" ve "kentsel kimliği koruma" yolundaki kararları gösterilmiştir. Diğer örnek olan Southwark'taki Tanner Street projesinde ise eski bir sanayi bölgesi iken soylulaştırmaya uğrayan bölgede, duvarla çevrili bir sanayi alanının daha önce açık olan kapıların kapatılmasıyla bir kapalı siteye dönüştürülmesi söz konusudur. $\mathrm{Bu}$ proje, yerel yönetim tarafından bir itirazla karşılaşmamış ve onaylanmıştır. Projede yalnızca oturanların açabileceği bir kapı bulunmakla birlikte 24 saat güvenlik görevlisi bulunmamaktadır. Ayrıca projeyi yapan şirket ile yerel yönetim arasındaki pazarlıklar sonucu, erişilebilir konut fonuna aktarılacak 40.000 sterlin 
250.000'e yükseltilmiştir. Gooblar (2002, 332), şu sonuca varmaktadır: İngiltere'de kapalı siteler, özel olarak bir politika konusu olarak görülmemekte ve diğer konut alanlarından farklı bir işleme tabi tutulmamaktadır. Bu konuda yerel halkın ve yerel yönetimin tutumu belirleyici olmaktadır. Benzer şekilde, Atkinson vd (2004), İngiltere genelinde yaklaşık 1000 kapalı site olduğunu belirtmişler ve yaptıkları araştırmada, çok az sayıda yerel yönetimin bu konuya özel politikalar geliştirdiklerini belirtmişlerdir. Gooblar (2002, 326), Amerika Birleşik Devletleri'nde farklı bir planlama sistemi bulunmasına rağmen, “ABD'deki birçok belediye kapalı sitelerin yapımını, kapıların dışındaki kişiler için önemli olumsuz etkileri olduğundan engelleme ihtiyacı hissetmektedir" diye yazmaktadır. Ancak bu yaklaşımın bütün yerel yönetimler için geçerli olmadığının da altını çizmektedir. Bilindiği gibi ABD, kapalı sitelerin çok sayıda rastlandığı belki de ilk ülkedir (Blakely ve Snyder, 1999, Low, 2004).

Böylece ABD örneğinde de kapalı sitelere karşı ülke ölçeğinde bir planlama politikası olmadığı ve yerel yönetimlerin bu konuda farklı tutumlar benimsedikleri görülmektedir. Gelişmekte olan ülkelerde ise Türkiye'de olduğu gibi planlama ile kentsel gelişimi yönlendirmenin yetersiz kaldığı ve kapalı sitelerin örneğin Mexico City'de denetim dışı olduğu (Giglia, 2003) ve Çin'de ise yerel yönetim giderlerini

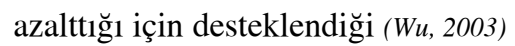
belirtilmektedir.

Bu örnekler içinde Kanada, kapalı sitelere karşı tutarlı bir yaklaşımın benimsendiği tek örnektir. Toplumsal ve mekansal bütünlüğe tehdit oluşturabilecek konut alanlarının daha baştan engellenmesinin ve girişimcilere kentsel rant artışından paylar vererek ödüllendirmek yerine, bu türden yapılaşmanın cezalandırılmasının (ruhsat ve izin vermemek, kat mülkiyetine kistlama getirmek) bir strateji olarak benimsendiğ $i$ görülmektedir. Bu planlama yaklaşımı oldukça önemli dersler barındırmaktadır. Planlama politikalarının farklı ölçeklerde, farklı kapsamlarda tamamen kamusal
Resim: 3

istanbul, Küçükçekmece'de gecekondudan dönüşen alanlarda kentsel donatı ve mekansal kalite yetersizliği (Nisan 2008, kişisel arşiv).

Resim: 4

Kadıköy, Caddebostan'da, bölgede artan emsal değeri dolayısıyla yıkılan bir konut (Ocak 2009, kişisel arşiv). Resim: 5 Ormana yakın olmasını bir pazarlama öğesi olarak kullanan kapalı site tanıtımı. Kaynak: http://www.ormanada.com/\#/ Adim_Adim_ormanada, erişim tarihi: 29.07.2012.

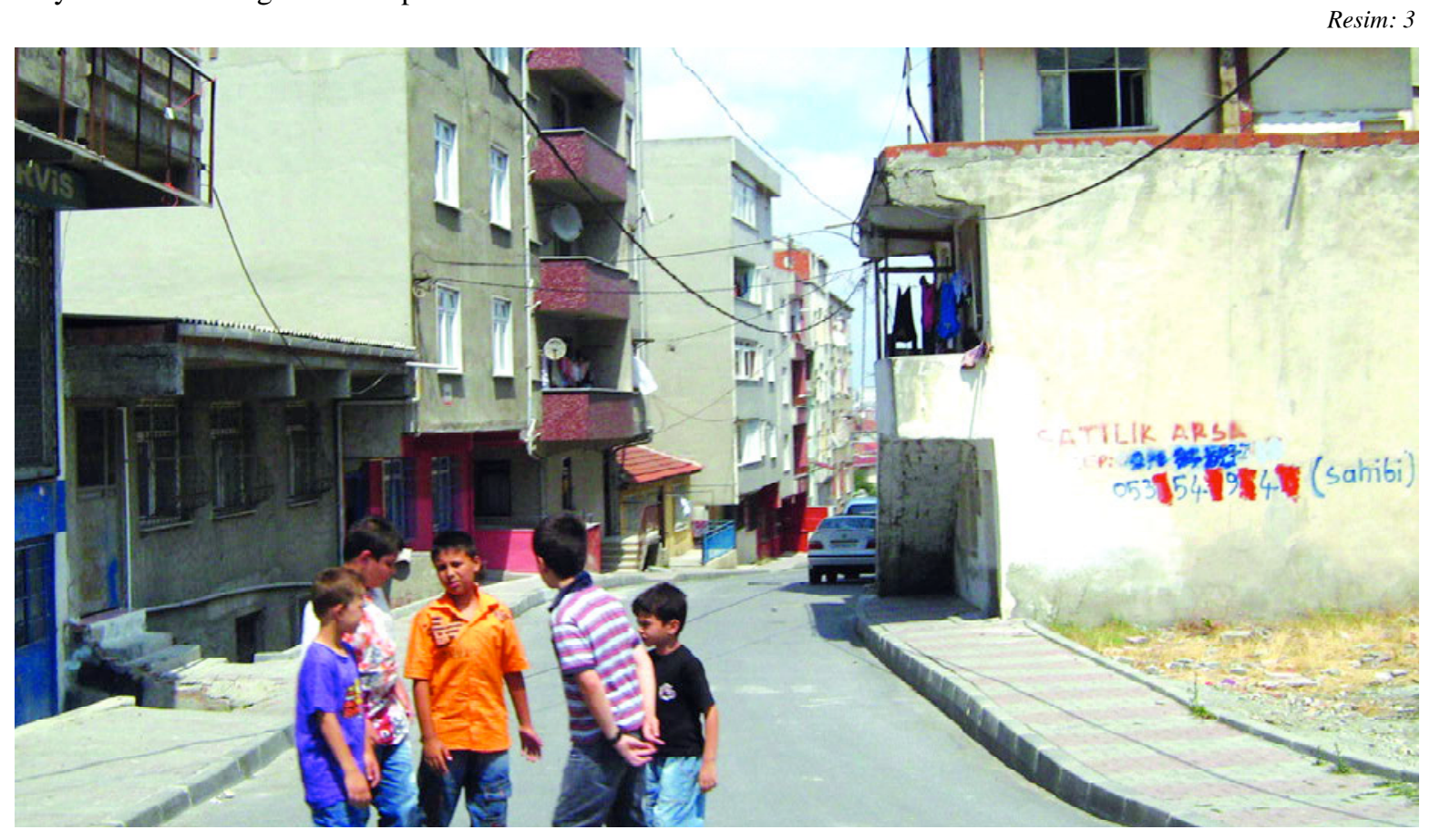

$38 \mid$ Sayı 14, 2012 


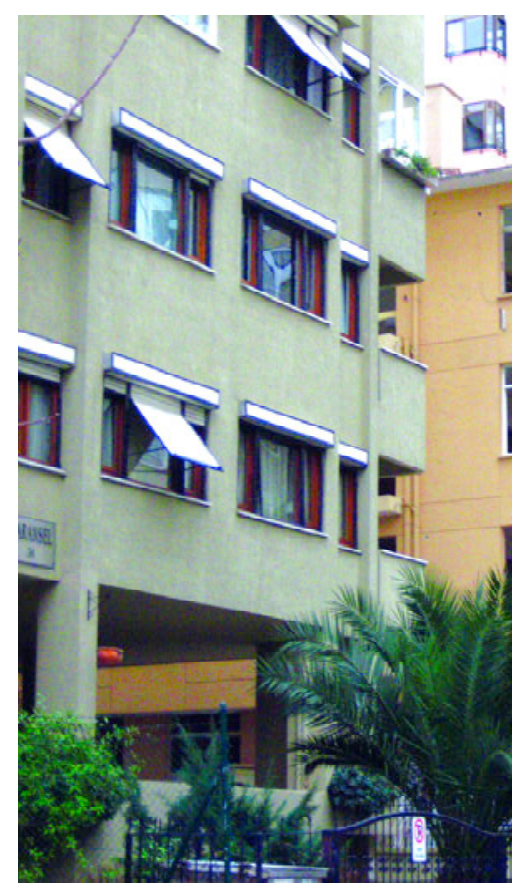

Resim:4 politika üretmek için kullanılması, alınacak en önemli derstir. Emlak sektörünün denetimsizce ve sorumsuzca desteklenmesinin, yerel yönetimlerin asli görevleri arasında olmadığının hatırlanması açısından da önemli dersler sunmaktadır. Planlama sürecinin en basit anlamıla kamusal sorumluluk gerektiren bir eylem alanı olduğu ve yerel yönetimlerin de bu konuda tek sorumlu aktör olduğu, bu örnekte açık olarak görülmektedir.

\section{Istanbul'da kapalt siteler:}

Günümüz İstanbul'u, bir yanda gecekondudan dönüşen ve aşırı yoğunluklu, sosyal ve kentsel donatılar açısından oldukça yoksun alanlarla yapılanmakta, merkezde kalan konut alanları giderek kentsel donatılar açısından yetersizleşme pahasına parsel bazında yap-satçı faaliyetler sonucu giderek yoğunlaşmaktadır (Resim 3 ve 4). Kentin çeperlerindeki eski tarım ve orman arazileri üzerine kurulan siteler, aile odaklı bir yaşam tarzı üzerinden pazarlanmaktadır (Resim 5).

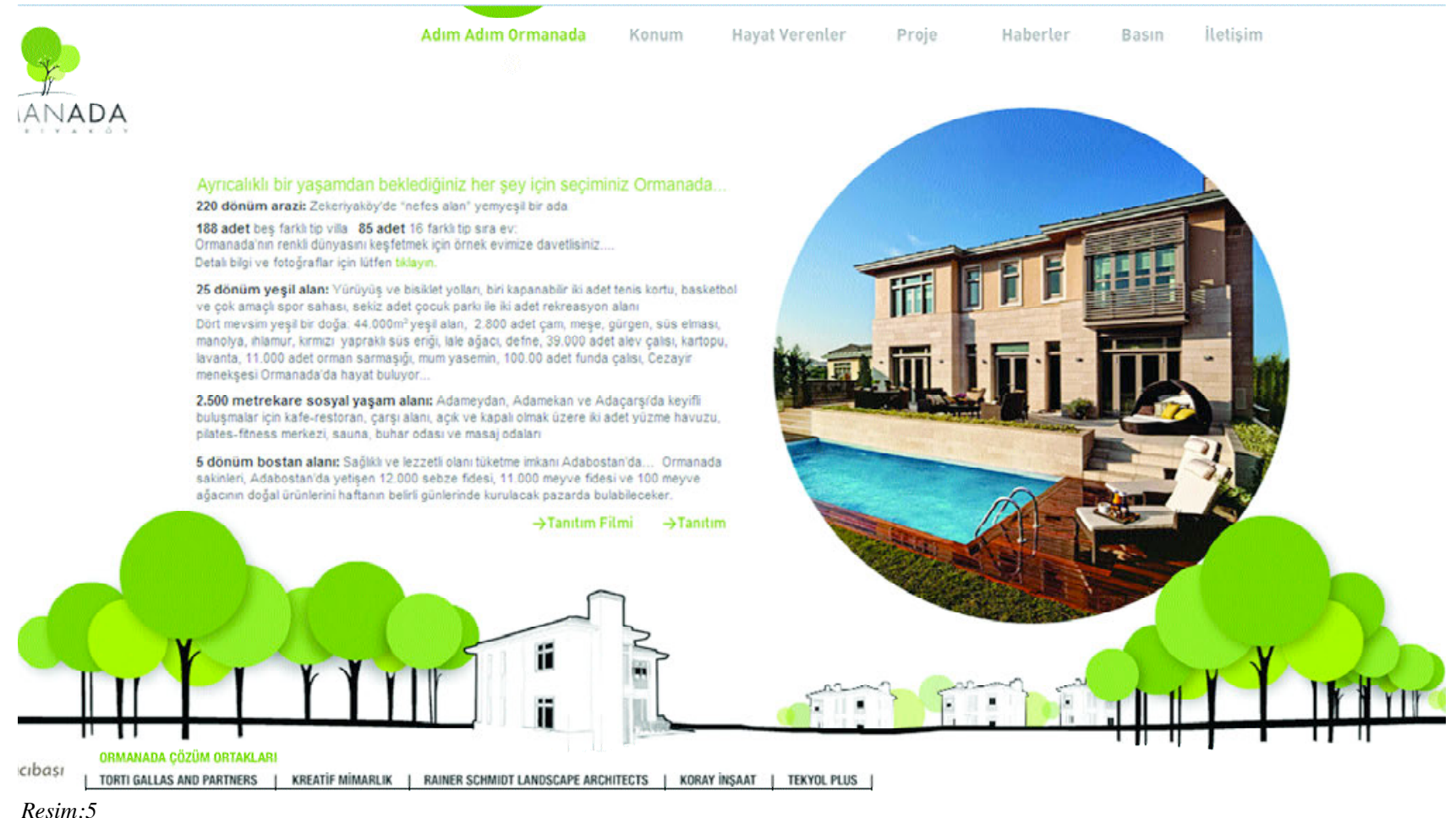

Resim:5 


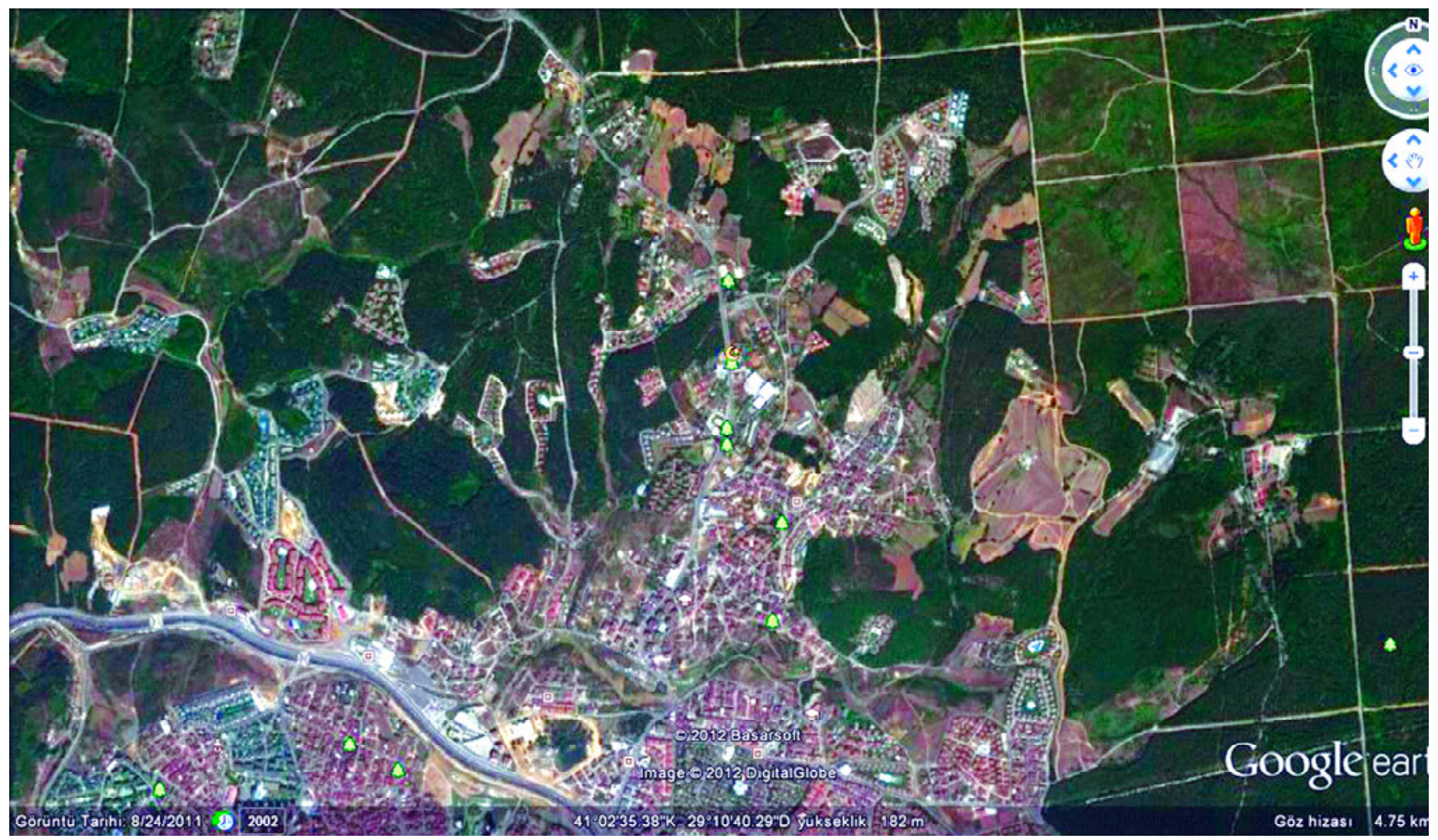

Resim: 6

Kapalı siteler, genellikle geniş alanlara gereksinim gösterdiklerinden, daha çok kentlerin çeperlerine doğru

yayılmaktadırlar. Orman ve tarım arazileri, yüklenicilerin ve girişimcilerin büyük parçalar halinde arazi edinmesine olanak sağlamaktadır. Dolayısıyla, bu türden büyük parçalar halindeki denetimsiz yayılma, doğal ve çevresel değerleri tehdit etmektedir. İstanbul'da kapalı siteler çoğunlukla kentin çeperlerinde yer alan Göktürk, Çekmeköy, Zekeriyaköy gibi geniş tarım ve orman alanlarının bulunduğu alanlarda yer seçmektedirler (Resim 6 ve 7). Bununla birlikte Marmara kıyılarında, deniz manzarası ya da Boğaz sırtlarında Boğaziçi manzarasına hakim olan yerlerde de konumlanmaktadirlar.

Son olarak, planlama açısından kapalı siteler düşük yoğunluklu yapılaşmayı teşvik ettiklerinden hem kentin yayılma sürecini hızlandırmakta, doğal koruma alanlarını hızla tüketmektedirler hem de otomobile bağımlı bir yaşam biçimi kurduklarından çevre yolları üzerindeki ulaşım yoğunluğunu ve çevresel kirliliği artırmaktadırlar. Diğer yandan MİA içinde inşa edilen aşırı yoğunluklu rezidanslar ve bloklar ise hem merkezi parçalamakta hem de merkezdeki yoğunluğu aşırı yükselterek altyapı ve ulaşım sorunlarına yol açmaktadırlar. Bununla birlikte konut alanlarında yükseltilen kentsel rantı, belli bir kesimin tekeline sunmaktadırlar. Bütün bunlar, sonuçta rant üzerine kurulu bu konut alanlarının yarattığı baskılar dolayısıyla bütün kentlilerin yaşam niteliklerinin düşmesine neden olmaktadır. Harvey'in (2001) belirttiği gibi kent içindeki konumsal özelliklere eklenen nitelikler, piyasa içinde rantı azamileştirmeye yönelik tekelleşmeyi doğurmaktadır. Kapalı sitelerin çevresel etkileri orman alanları ve havzalara yayılmaları dışında, çevre ve peyzaj düzenlemelerinin

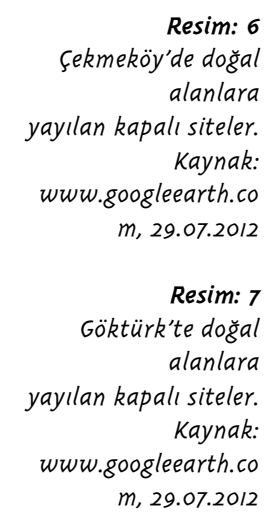

Resim: 6

lanlara

siteler.

sim: 7

anlara

Kaynak:

m, 29.07.2012 


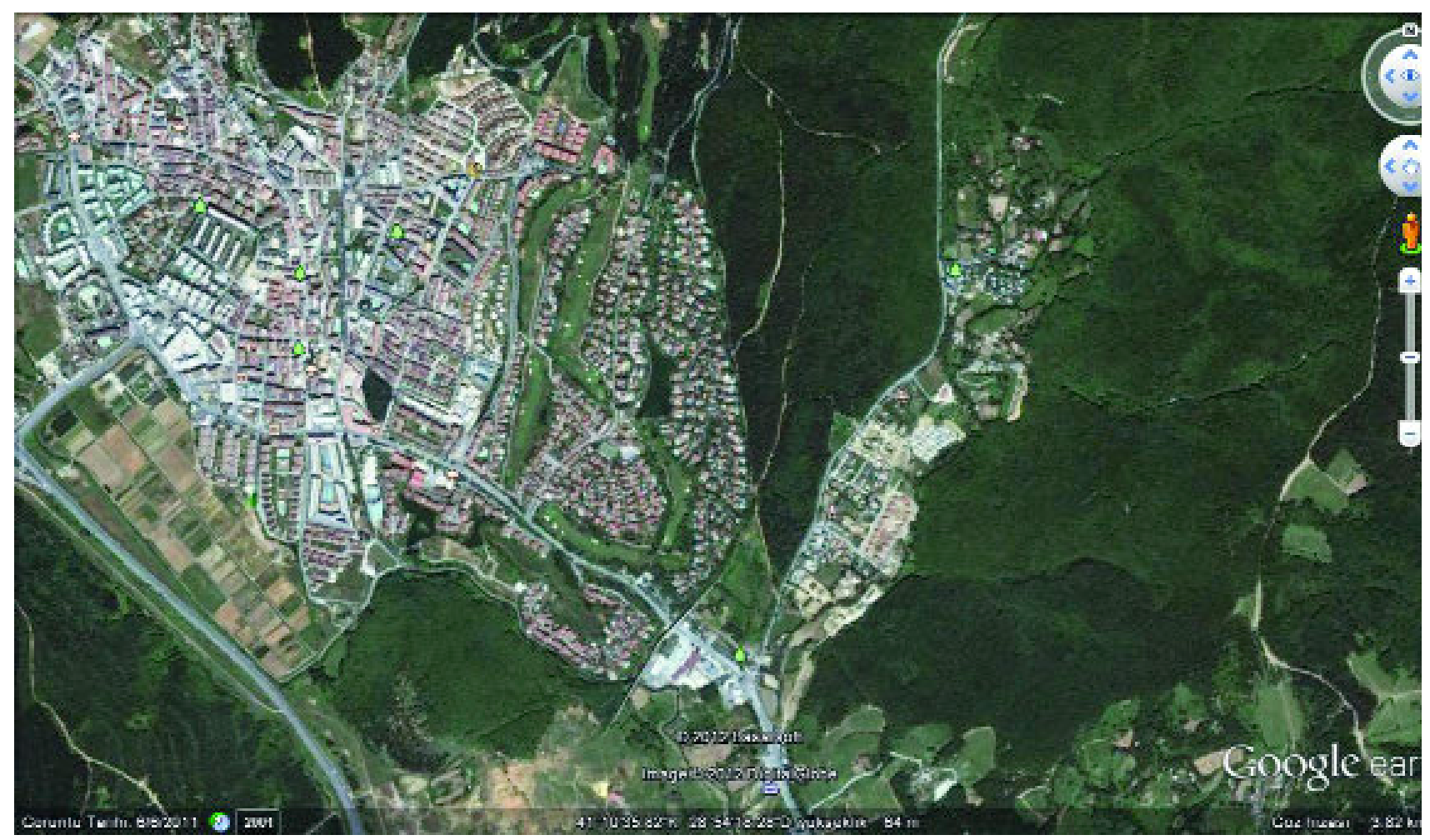

Resim: 7

gerektirdiği su tüketiminde tasarruf önlemlerinin alınmaması (Ekici, 2011) da bir diğer sorunu oluşturmaktadır. Bununla birlikte çöp toplamada atık ayrıştırmayı kolayca düzenleyebilecek bir özel yönetim birimine sahip olmalarına rağmen, Çekmeköy'deki 6 kapalı sitede yapılan araştırma, atıklar için de özel bir önlem alınmadığını göstermektedir (Ekici, 2011).

Bugün, özellikle İstanbul'da kapalı sitelerin tümü, büyük inşaat şirketleri tarafından üretilmektedir. Kapalı sitelerin üretiminde kamu ve özel sektör işbirliğine de gidilmektedir (TOKI, url, 2012). Hâsılat paylaşımı ve kaynak geliştirme olarak tanımlanan bu yaklaşım, kentsel rantın transferi yoluyla iki açıdan sorun oluşturmaktadır. İlki, kamu arazilerinin özel sektöre devredilmesi, ikincisi, İstanbul, Ankara, İzmir gibi yüksek rant sağlayan kentsel alanlardaki rantın buralarda kullanılmak yerine, daha küçük yerleşmelere transfer edilmesidir. Bu durumda, daha parçalı bir toplumsal yapı sunmasına rağmen, büyük kentlerde düşük gelir grupları için inşa edilen konut alanlarının oranı düşmektedir. Bunlar dışında, kapalı sitelerin konumsal özelliklerine bağlı olarak yarattıkları rantın kamuya geri dönüşü bulunmamaktadır. Örneğin, kapalı sitelerin yarattığ raylı sistemi olmayan ve toplu taşıma olanakları zayıf olan bölgelerde toplu taşınım kullanmak zorunda olan kişilerin trafikte daha fazla zaman geçirmesine yol açmaktadır. Böylece azınlığın elinde bulundurduğu avantajlar, bu alanlara yapılan ilk altyapı yatırımlarının da yerel yönetim tarafından karşılandığı düşünülürse, diğer kesimler için dezavantaj haline gelmektedir.

Bu sitelerin yapılmasında özel sektörün başı çektiği görülmektedir. Ancak, TOKİ de arsa karşılığg gelir paylaşımı esası ile 
sitelerin üretilmesine destek olmaktadır. Bu çalışma kapsamında, TOKİ resmi internet sitesinde İstanbul'da inşa edilen konut alanlarına ilişkin 2012 yılına ait veriler derlenmiştir. Günümüzde TOKİ'nin İstanbul'da ürettiği konutlar, hâsılat paylaşımı, kaynak geliştirme uygulamaları, konut ve sosyal donatı uygulamaları, idare konut uygulamaları, kentsel yenileme, alt gelir grubu ve yoksul grubu uygulamaları olarak ayrılmaktadır. Özel sektör işbirliği ile yapılan ve kapalı site olarak inşa edilen projeler kaynak geliştirme ve hasılat paylaşımı içinde yer almaktadır. Bunun dışında idare kendi konut uygulamalarını, hitap edilen kesimlere göre ayırmamaktadır. Buna göre, en yüksek sayıda 46759 konutla hâsılat paylaşımı ve 26343 konutla kaynak geliştirme uygulamaları görülürken, alt gelir grubu ve yoksul kesim için yalnızca iki projede 766 konut yaptırıldığının belirtildiği görülmektedir. Orta ve alt sinıflara yönelik olarak ise konut ve sosyal donatı uygulaması adı altında 16537 konut ve idare konut uygulaması adı altında 20931 konut üretilmiş ya da üretilmesi planlanmaktadır (TOKI, url, 29.07.2012). Toplam olarak kabaca 73102 konut üst gelir grubunu hedeflerken, alt ve orta gelir grubunu hedefleyen 38234 konut inşa edilmiş ya da planlanmıştır (Tablo 1).

İstanbul, alt ve orta gelir grubu açısından daha fazla konut alanlarına gereksinim duyulan bir metropoldür. TOKİ örneğinin açıkça gösterdiği gibi, kamu alanı konut sorununa sosyal adalet ilkesi çerçevesinde değil, piyasadaki aktörler gibi gelir elde etmeye yönelik olarak ve tüketim kültürü dinamiklerini kullanarak müdahale etmektedir. Hâsılat paylaşımı ve kaynak geliştirme uygulamaları, özel sektör ile işbirliği içinde geliştirilen kapalı sitelerden oluşmaktadır ve oranları, toplamda

\begin{tabular}{|l|l|l|}
\hline TOKİ Uygulaması & Sayı & $\begin{array}{l}\text { Oran } \\
(\%)\end{array}$ \\
\hline Kaynak Geliştirme & 26343 & 0,22 \\
\hline Hâsılat Paylaşımı & 46759 & 0,40 \\
\hline İdare Konut Uygulaması & 20931 & 0,18 \\
\hline Konut ve Sosyal Donatı & 16537 & 0,14 \\
\hline Alt Gelir Grubu/Yoksul Grubu & 766 & 0,01 \\
\hline Kentsel Yenileme & 6289 & 0,05 \\
\hline Afet Konutu & 114 & 0,00 \\
\hline Toplam & 117739 & 1,00 \\
\hline
\end{tabular}

$\%$ 62' yi bulmaktadır. Orta ve alt gelir grubuna yönelik uygulamaların toplamı ise \% 33'te kalmaktadır. Alt gelir grubu ve yoksul grubu olarak adlandirilan kategorideki toplam uygulama ise \% 1'i ancak bulmaktadır. Bunun içinde yoksul grubu uygulamalarının toplam konut sayısı 88 konut ile \% oran içinde yer bulamamaktadır. Bu değerler, TOKİ'nin İstanbul'daki uygulamalarının daha çok kentsel arsa değerlerinden faydalanarak gelir elde etmeye yönelik olduğunu göstermektedir. Burada iki önemli sorun ortaya çıkmaktadır. Birincisi, hanelerin gereksinimlerine göre konut üretilmemesidir. İkincisi ise üretilen konut alanlarının oluşturdukları kentsel çevre açısından olumsuz sonuçlar doğurmasıdır. Üst gelir grubu için üretilen kapalı sitelerin toplumsal ve çevresel etkileri bu makale içinde önceki kısımlarda tartışıldı. Orta ve alt gelir grubu uygulamaları da oluşturdukları kentsel çevre açısından olumsuz örnekler teşkil etmektedirler. (Resim 8).

İstanbul'un 2009 yılında onaylanan en son Çevre Düzeni Planı verilerine göre, İstanbul'da orman alanlarına yapılanmış konutların \% 16'sı düzensiz konut alanlarından oluşmaktadır (IBB, 2009, 315). Plan raporunda yer verilmemekle birlikte bu veriden çıkarılabilecek sonuç, orman alanlarından yapılaşmış olan geri kalan 


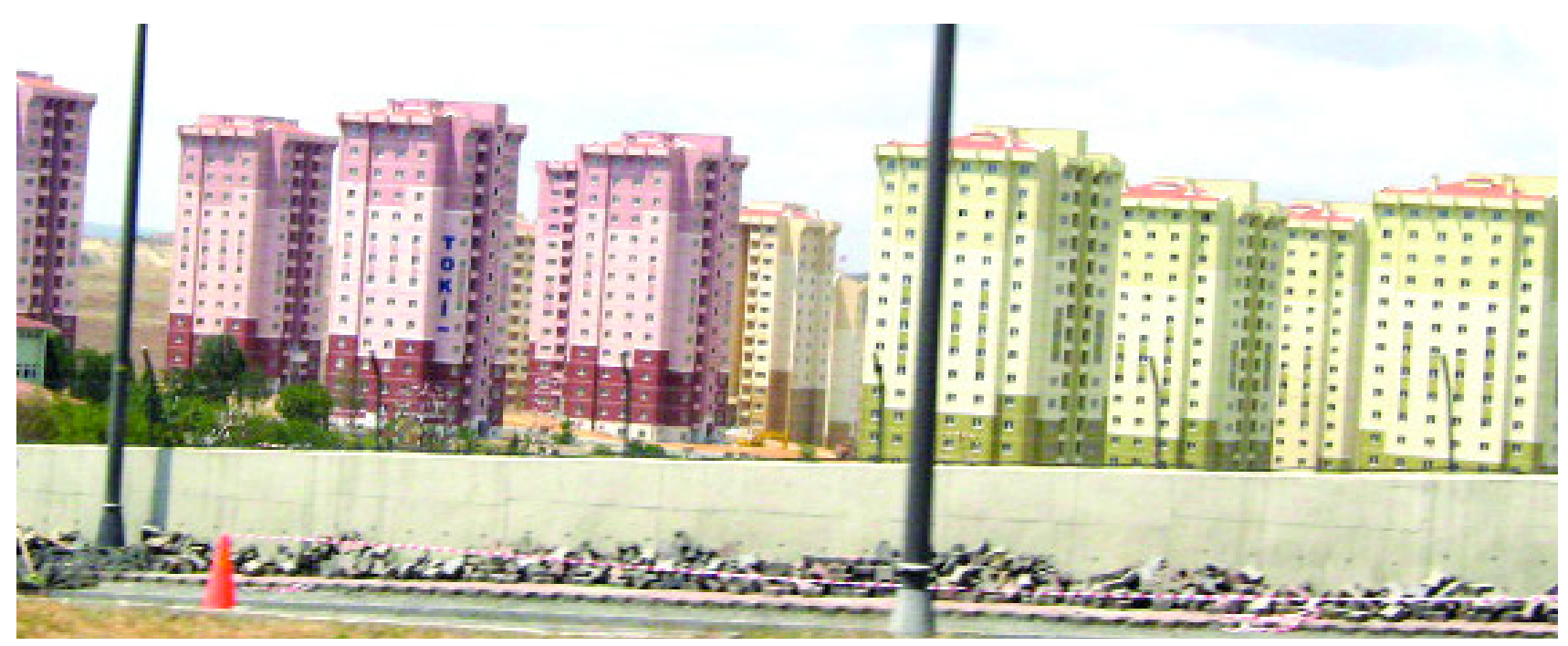

Resim: 8
\% 84'ün düzenli konut alanı olduğudur. Bunların içinde kapalı sitelerin büyük bir yeri olduğunu tahmin etmek hiç de güç değil (Resim 6 ve 7). Zaten plan raporunda da “Düşük yoğunluklu siteler İstanbul'un orman ve tarım alanlarını, içme suyu havzalarını tehdit edecek şekilde gelişmiştir" denilmektedir (IBB, 2009, 324). Bununla birlikte, "Konut gelişme alanlarının; orman alanları, içme suyu toplama havzaları, tarım alanları ve jeolojik sakıncalı alanlar gibi yerleşime uygun olmayan alanların dişında seçilmesi" (IBB, 2009, 536) ve "İstanbul'da yaşayan tüm kesimleri kentle bütünleştiren kentsel donatı alanlarının ve kamusal açık alanların kent bütünü içinde yeterli, dengeli ve kaliteli hale getirilerek; kentsel hizmet ve firsatlardan toplumun tüm kesimlerinin yararlanabilme olanaklarının arttırılması" (IBBB, 2009, 537) dişında bir karar getirilmemiştir.

\section{Sonuç ve Değerlendirme}

Dışa kapalı konutlaşmanın yarattığı en önemli sonuç, sosyal ve mekânsal ayrışmayı keskinleştirmeleridir. Kentin mekânsal olarak gelir gruplarına göre parçalanması ve konut alanlarının duvarlarla çevrilmesi, kentteki varsıllık ve yoksulluğu daha keskin olarak hissedilir hale getirmektedir. Duvarlarla çevrelenen sokaklar, kapalı kapılar ardında kalan özelleştirilmiş ortak alanlar kamusallığın ve kentselliğin sorgulanmasına neden olmaktadır. Bunlara ek olarak, kapalı siteler şeklinde kentsel yapılanma, kent mekânının geçirgenliğini düşürdüğünden erişilebilirlik ve kamusal kullanım açısından da sorunlara yol açmaktadır.

Bu konutlaşma biçimi, piyasanın karlılık ölçütleri ile konutun bir metaya, prestij sağlayan bir tüketim malına dönüşmesi ile pazarlama konusu olması dolayısıyla hız kazanmıştır. Pazarlanabilirliğin toplumsal altyapısını, tüketim toplumu dinamikleri oluşturmaktadır. Bu durumda konut üretimi, "herkese erişilebilir ve yaşanabilir konut" ölçütlerini sağlamaktan uzaklaşmaktadır. Konutlaşmanın kentsel arsa değerinden pay elde etmeye yönelik üretim biçimi, var olan eşitsiz yapıyı derinleştirmektedir. Kamu alanı, dar gelirli kesimlerin konut edinmesine yönelik politikaları izlemektense, hem konut üretimindeki kamu aktörleri hem de yerel yönetimler, emlak sektörünü hareketlendirecek yeni alanlar açma yönelimini 
desteklemektedir. Böylece konuta erişimde gelir düzeyine göre var olan eşitsizliğin azaltılması bir yana, kamu eliyle arttırıldığı görülmektedir.

Konutlaşmanın bütüncül planlamadan yoksun olması ve kent yönetiminin sosyal eşitlik ve sosyal adalet üzerine politikalar geliştirmemesi ve konutlaşmanın piyasa süreçlerine terk edilmesi ile sonuçlanmaktadır. Yapılan kent planları da piyasaya hizmet eder hale gelmektedir. Bu durum ise gelire ve ihtiyaca yönelik olarak yaşanabilir konut üretilmemesi ile sonuçlanmaktadır. Sonuçta ortaya çıkan, düşük kaliteli toplu konutlar, otopark ve bazı spor alanları ile bakımlı çevreye sahip, ancak kentle ilişkisiz güvenlikli siteler ve parsel üzerinde yap-satçılık ile giderek yoğunlaşan kentsel alanlardır.

Konutlaşmanın piyasaya terk edilmesi ve bu konuda eşitlikçi politikaların geliştirilmemesi, kamunun elindeki araçları piyasa süreçlerine uygun şekilde kullanması, konuyu daha içinden çıkılmaz hale getirmektedir. Böylece çıkış noktası dar gelirlilere konut üretmek olan ve her kesim için yaşanabilir konutlaşmayı hedeflemesi beklenen TOKİ gibi kamu kuruluşları da kapalı site biçiminde konut üreterek ya da, bu türden üretime kaynak geliştirme ve hâsılat paylaşımı adı altında destek vererek toplumsal ve mekânsal ayrışmayı desteklemektedir. Bu süreçte, kamuya ait arsa üzerinde konut üretimi de kapalı sitelere bırakılmış olmakta, arsa stoğu bu yolla eritilmektedir. Aynı zamanda çevresel, toplumsal ve mekânsal açıdan sorunlu bir kentsel gelişme biçimini de teşvik etmektedirler. Kamu kuruluşlarının ürettiği alt gelir grubu konut alanlarının da kentle ilişkileri açısından kapalı site biçimindeki yapılaşmadan çok da farkı bulunmamaktadır ve alt gelir grubu

$44 \mid$ Sayı 14, 2012 uygulamalarının yarattığ kentsel düzen de niteliksiz ve sorunlu olmaktadır. Donatı alanları, çevre kalitesi ve sunduğu yaşama ortamları açısından, toplu konut uygulamalarının çoğunlukla başarısız olduğu görülmektedir. İstihdam alanları ve kentsel merkezler ile bağlantısı kurulmamış olan bu tür konut alanları, ulaşım sorunları, çevresel sorunlar ve niteliksiz yapılaşmaları dolayısıyla toplumsal ve psikolojik sıkıntılar yaratan alanlar haline gelmektedirler.

İstanbul'un yıpranmış konut stoğu, kent içindeki mevcut yapılaşmış konut alanları açısından önemli sorunlardan birini oluştururken, TOKİ gibi konut üretimine yönelik kuruluşların ya da merkezi ve yerel yönetimlerin depreme karş1 güçlendirme ve yenileme için fon ve destek yaratmadığı görülmektedir. Oysaki İstanbul'un mevcut konut alanlarının yenilenmesi ve yaşanabilir hale getirilmesi gerekmektedir. Rant yaratmaktansa yaşanabilir kentlere erişmeyi hedefleyen projelerin plan kapsamında geliştirilmesinin kapalı site tarzı sosyal ve mekânsal açıdan olumsuz sonuçlar doğuran konutlaşmayı engellemede bir araç olarak kullanılabileceği düşünülmelidir. Ancak bunun yerine kamu alanı, kentin yayılmasını sağlayan siteler yaparak kentin plansız büyümesini desteklemektedir.

Üst ölçekte, kamu politikalarının ve planlamanın kentsel gelişmeyi düzenleyip yönlendirememesi, alt ölçekte mahalle (komşuluk birimi) düzenine de olumsuz etkilerde bulunmaktadır. Üst ölçekteki eşitsizlik, kişilerin yaşam alanları açısından, mahallenin dağılması ile görünür ve belirgin hale gelmektedir. Mahalle örgütlenmesi, konut alanları 
planlamasında temel öğe olarak yeniden ele alınmalı, günümüz koşullarında kentsel hizmetlerin dağıtımı konusunda aşamadı $\breve{g}_{1}$ sorunlar yeniden değerlendirilmelidir. Kentsel sağlık ve eğitim hizmetlerinin özelleşmesi, yeniden dağıtım mekanizmasının piyasa koşullarında gerçekleşmesi ve gelir dağılımındaki adaletsizlik, mekansal düzeyde mahalle düzeninin ortadan kalkmasına neden olmaktadır. Tüm bu sorun alanları, tek tek ele alınıp geniş bir vizyon çerçevesinde tartışılarak yeniden yorumlanması gereken konuları oluşturmaktadır. Çözüm, kısa vadede geçici önerilerde bulunmak yerine bu sorunları çözecek planlama araçlarının geliştirilmesinde aranmalıdır. Çözüm araçları, kentsel sorunların ve yerel yönetimlerin yaklaşımlarının yeniden ele alınmasıyla, geniş çerçevede üretilmeye çalışılmalıdır. Son olarak kamu alanında sosyal eşitsizliği dengelemeyi hedefleyen kentsel politikalar ve bu politikaları hayata geçirecek plan ve uygulama araçları üretilmeden, konut sorununu çözmek mümkün görünmemektedir. Konut sorununa temel yaklaşım, sunum biçimini, tüketimin belirlediği piyasacı yaklaşım yerine, herkes için yaşanabilir ve nitelikli konut ve kentsel çevre üretimi olmalıdır

\section{KAYNAKÇA}

Atkinson, R. 2006. Padding the Bunker: Strategies of Middle-class Disaffiliation and Colonisation in the City. Urban Studies, Vol. 43, No. 4, pp. 819-832

Atkinson R, Blandy S, Flint J, Lister D. 2004. Gated Cities of Today: Barricaded Residential Development in England. Gated Communities: Building Social Division or Safer Communities? 18-19 September 2003, Glasgow.

Bali, R. N. 2002. Tarz-1 Hayat'tan Life Style'a -Yeni Seçkinler, Yeni Mekanlar, Yeni Yaşamlar. İstanbul: İletişim Yayınları

Barthes, Roland. 1998. Çăgdaş Söylenler. çev. Tahsin Yücel. İstanbul: Metis Yayınları

Baudrillard, J. 2004. Tüketim Toplumu. çev. H. Deliçaylı, F. Keskin. İstanbul:.Ayrıntı Yay.

Blakely, E. J; Snyder, M. G. 1999. Fortress America, Gated Communities in the United States, Washington
D.C: Brookings Institution Press

Bourdieu, P. 1995. Pratik Nedenler. İstanbul: Kesit Yayıncilık

Davis, M. 1992. City of Quartz. New York: Vintage Books, Ekici, T. 2011. Sürdürülebilir Kentsel Gelişme Çerçevesinde Kapalı Sitelerin İrdelenmesi: İstanbul Çekmeköy Örneği. yayınlanmamış Yüksek Lisans Tezi, Mimar Sinan Güzel Sanatlar Üniversitesi, FBE, İstanbul.

Erkip, F. 2010. Community and neighborhood relations in Ankara: An urban-suburban contrast. Cities, 27 (2010) pp. 96-102

Firidin Özgür, Ebru. 2006. Sosyal ve Mekansal Ayrışma Çerçevesinde Yeni Konutlaşma Eğilimleri: Kapalı Siteler, İstanbul, Çekmeköy Örneği yayımlanmamış doktora tezi, Mimar Sinan Güzel Sanatlar Üniversitesi, FBE, İstanbul

Firidin Özgür, Ebru. 2011. Konut Alanlarında Güncel Eğilimler ve Mahalle Olgusu. TOL, güz 2010bahar 2011, Kayseri MO Yayını, ss.16-24.

Giglia, A. 2003. Gated Communities in Mexico City. Gated Communities: Building Social Division or Safer Communities?, 18-19 September 2003, Glasgow.

Gooblar, A. 2002. Outside the Walls: Urban Gated Communities and their Regulation within the British Planning System. European Planning Studies, Vol. 10, No. 3, pp. 321-334.

Grant, J. 2003. Planning responses to gated communities in Canada. Gated communities: building social division or safer communities?, 18-19 September 2003, Glasgow.

http://www.bristol.ac.uk/sps/cnrpapersword/gated/grant.doc, 20.09.2004.

Harvey, David. 2001. Spaces of Capital, New York: Routledge

Işık, O, Pınarcıŏ̆lu, M. 2003. Nöbetleşe Yoksulluk: Gecekondulaşma ve Kent Yoksulları: Sultanbeyli Örneği. İstanbul: İletişim

İBB, Şehir Planlama Müdürlüğü. 2009. 1/100000 Ölçekli İstanbul Çevre Düzeni Planı Raporu.

Keyder, Çağlar. 2000. Enformel Konut Piyasasından Küresel Konut Piyasasina. İstanbul Küresel ve Yerel Arasında içinde: Ç. Keyder, der. İstanbul: Metis. ss. 171-191,

Le Goix, R. 2003. Gated Communities Sprawl in Southern California and Social Segregation. Gated com munities: building social division or safer com munities? 18-19 September 2003. Glasgow

Low, S. 2004. Behind the Gates, Routledge

Öncü, Ayşe. 1999. 'İdealinizdeki Ev’ Mitolojisi Kültürel Sınırları Aşarak İstanbul'a Ulaştı. Birikim. 123, temmuz 1999, ss. 26-46

TOKİ url, (erişim tarihi 29.07. 2012):

http://www.toki.gov.tr/programlar/ihale/c_illist.asp?x_ilko $\mathrm{du}=34$

Wu, F. 2003. Rediscovering the 'gate' under market transi tion: from work-unit compounds to commodity housing enclaves, Gated Communities: Building Social Division or Safer Communities? 18-19 September 2003, Glasgow. 